\title{
Pelatihan Pemanfaatan Modal Sosial Masyarakat Lokal di Kelurahan Limau Manis Selatan Kecamatan Pauh, Kota Padang
}

\author{
Indah Adi Putri, Bakaruddin Rosyidi, Aidinil Zetra, Asrinaldi, Tengku Rika Valentina, \\ Tamrin, Dewi Anggraini, Mhd. Fajri, dan Didi Rahmadi \\ Fakultas Ilmu Sosial dan Ilmu Politik, Universitas Andalas, Kampus Limau Manis, Padang, 25163. Indonesia \\ E-mail: indahputri1981@yahoo.com
}

Keywords: social capital, social network social ties, community groups
Kata Kunci: modal social, jaringan social, ikatan social, kelompok masyarakat

\begin{abstract}
This paper discusses the importance of social capital in the midst of society. Social capital can be interpreted simply as a social bond. These social ties arise because of trust and social networks. In reality, this social bond has not been and is not utilized well. This dedication was carried out in the Limau Manis Selatan Village, Pauh District, Padang City. The approach used in the implementation of the community service program is a participatory Rural Appraisal (PRA) approach. In this service, several things are discovered, namely, first, social capital will be destroyed if there are no tabayyun / checks and checks on any new developments or information. Second, social capital will be strong if the common goals are known and agreed upon by all elements of society. Third, all parties must have the same intention and motivation. Fourth, in the community there will be groups that have problems, each group has rules that must be obeyed, as long as the rules are followed, then the organization or groups will continue to run. Fifth, for community cohesiveness must follow a joint decision. Sixth, eliminate suspicion and personal pride.
\end{abstract}
ABSTRAK
Tulisan ini membahas tentang pentingnya modal sosial dalam proses pembangunan di tengah - tengah masyarakat. Modal sosial secara sederhana dapat diartikan sebagai sebuah ikatan - ikatan sosial. Ikatan - ikatan sosial tersebut muncul karena adanya kepercayaan dan jaringan sosial. Pada realitanya, ikatan sosial ini belum dan kurang dimanfaatkan dengan baik. Pengabdian ini dilaksanakan di Kelurahan Limau Manis Selatan, Kecamatan Pauh Kota Padang. Pendekatan yang digunakan dalam pelaksanaan program pengabdian kepada masyarakat adalah pendekatan partisipatif atau Participatory Rural Appraisal (PRA). Dalam pengabdian ini ditemukan beberapa hal yakni pertama, modal sosial akan hancur jika tidak ada tabayun/ cek dan ricek terhadap setiap perkembangan atau informasi baru. Kedua, modal sosial akan kuat jika tujuan bersama diketahui dan disepakati semua elemen masyarakat. Ketiga, semua pihak harus memiliki niat dan motivasi yang sama. Keempat, dalam masyarakat akan ada kelompok kelompok yang memiliki masalah- masalah, setiap kelompok memiliki aturan yang harus dipatuhi, sepanjang aturan diikuti, maka organisasi atau kelompok akan terus berjalan. Kelima, untuk kekompakan masyarakat, harus mengikuti keputusan bersama. Keenam, hilangkan rasa curiga dan kesombongan pribadi. 


\section{PENDAHULUAN}

Dalam berbagai elemen sosial di masyarakat terdapat berbagai ikatan-ikatan sosial. Ikatanikatan sosial tersebut muncul karena adanya kepercayaan dan jaringan sosial. Pada realitanya, ikatan sosial ini belum dan kurang dimanfaatkan dengan baik. Padahal, pemanfaatan ikatan sosial tersebut bisa menjadi sebuah modal sosial yang nantinya dapat membantu dalam pembangunan sosial dan politik. Modal sosial adalah salah satu kekuatan dalam melaksanakan pembangunan, sebab modal sosial adalah ikatan-ikatan yang tercipta karena interaksi yang dilakukan oleh individu-individu pada masyarakat dan bisa timbul dari kepercayaan dan jaringan sosial yang ada. Salah satu contoh dari ikatan sosial yang ada ditengah-tengah masyarakat yang bisa menjadi modal sosial adalah kelompok arisan. Selain itu, ikatan-ikatan informal lainnya yang termasuk kedalam modal sosial ialah ikatan kepemudaan, organisasi ibuibu. Di Kelurahan Limau Manis Selatan terletak di Kecamatan Pauh, Kota Padang. Kelurahan ini tergabung dalam Kecamatan Pauh yang terdiri dari 6 kelurahan lainya, diantaranya Binuang Kampung Dalam, Cupak Tangah, Kapalo Koto, Koto Luar, Lambung Bukit, Limau Manis Selatan, Limau Manis, Piai Tangah, Pisang. Berdirinya kecamatan ini adalah akibat pemekaran kota Padang yang sebelumnya hanya terdiri dari 3 kecamatan menjadi 11 kecamatan pada tahun 1979, serta menggabungkan beberapa nagari di sekitarnya untuk menjadi kelurahan dalam kota Padang.

Saat ini di Kelurahan Limau Manis Selatan, ikatan-ikatan sosial masyarakat sudah terbentuk, namun belum disadari bahwa ikatan-ikatan sosial tersebut dapat menjadi sebuah modal sosial yang dapat dikembangkan dan dimanfaatkan untuk berbagai hal termasuk dalam pembangunan sosial dan politik bahkan bisa menjadi jalan bagi pemerintah daerah untuk mensukseskan program-program pemerintah. Berdasarkan analisis situasi di atas, rumusan masalah yang dihadapi dalam pemanfaatan modal sosial di Limau Manis Selatan ialah Pertama, modal sosial yang terbentuk melalui berbagai bentuk kelompok masyarakat belum berjalan optimal sebagai suatu modal yang dapat berguna untuk pembangunan. Kedua, kelompok modal sosial dalam masyarakat berjalan secara partikular sehingga kurang terbangun hubungan diantara kelompok tersebut. Ketiga, kehadiran kelompok ini sebagai suatu modal sosial belum diberdayakan secara optimal oleh pemerintah ditingkat kelurahan untuk mensukseskan program-program pemerintah termasuk dalam bidang pembangunan sosial dan politik.

Di samping itu pengertian modal sosial pada tingkatan mikro adalah pada jaringan hubungan individu, konsep modal sosial ini diantaranya dikemukakan oleh Robert Putnam (1993) yang mengartikannya sebagai bentuk organisasi sosial, seperti jaringan hubungan individu atau rumah tangga, serta kumpulan nilai-nilai dan norma yang menciptakan eksternalitas yang berbentuk positif. Tetapi, perkembangan lebih lanjut mendorong Putnam untuk mengartikan eksternalitas ini tidak hanya berbentuk positif, tetapi juga negatif. Eksternalitas negatif ini dihasilkan oleh interaksi antara individu, eksternalitas negatif hanya menguntungkan warga kelompok, tetapi tidak warga diluar kelompok tersebut.

Selanjutnya, pengertian modal sosial secara mikro ini dikembangkan oleh James Colemen (1998) pada tingkatan messo. Pengertian modal sosial menurut Coleman adalah adalah variasi berbagai masyarakat (entities) yang terdiri dari dari beberapa aspek struktur sosial, serta memfasilitasi tindakan dan aktor tertentu baik aktor pribadi atau kelompok dalam struktur tersebut (p. 558) yang secara implisit hanya menilai pada hubungan antar kelompok daripada individu. Pengertian ini memperluas konsep ini tidak hanya pada sisi hubungan kelompok vertikal dan horizontal, tetapi perilaku pada masyarakat lain seperti perusahaan. Pengertian hubungan vertikal mengandung hubungan hierarki, serta distribusi tidak merata kekuasaan dikalangan anggotanya. Pengertian ketiga modal sosial mengandung lingkungan sosial dan politik, serta membentuk struktur sosial yang memungkinkan norma berkembang. Pandangan 
ini disamping mengandung hubungan inforam, serta seringkali bersifat lokal dan hierarkhis seperti yang terdapat pada konsep mikro dan messo modal sosial, tetapi juga mengandung hubungan pada tingkatan makro yang lebih bersifat resmi dan terlembaga, seperti rejim politik, aturan hukum, sistem peradilan, serta kebebasan sipil dan politik. Pandangan ini diantaranya dihasilkan melalui karya Mancur Olson (1982) dan Douglas North (1990), mereka menjelaskan institusi ini memiliki efek mendasar terhadap tingkat dan pola pembangunan ekonomi.

Terdapat hubungan komplementer yang sangat tinggi antara perkumpulan hierarkhis maupun vertikal dengan institusi tingkat makro ini, serta hubungan (coexistence) tersebut memaksimumkan dampak modal sosial dan outcome social dan egonomi yang dihasilkannya. Contohnya, intitusi makro bisa menyediakan lingkungan yang memungkinkan perkumpulan lokal bisa berkembang dan tumbuh; perkumpulan lokal ini bisa menunjang institusi regional dan nasional serta menambah tingkat stabilitas keduanya.

Pengaruh modal sosial terhadap pembangunan dihasilkan dari interaksi antara dua tipe khas modal sosial baik pada tingkat mikro, messo atau makro, diantaranya pada struktur dan kognitif. Struktur modal sosial menyediakan saling tukar menukar informasi, serta tindakan kolektif dan pengambilan keputusan melalui peranan tersedia, jaringan sosial, struktur sosial lainnya yang disediakan oleh aturan, prosedur dan preseden. Sepertinya, hal ini bersifat objektif serta dapat diamati susunannya dari luar. Sedangkan modal sosial kognitif menunjuk kepada norma yang disepakati, nilai-nilai, kepercayaan, sikap serta keyakinan. Karenanya, ini bersifat lebih subyektif dan konsep yang tidak bisa diraba (Uphoff, 2000).

Aspek kognitif dan struktural tidak mesti berhubungan sama lain, seperti kerjasama diantara tetangga yang diikat oleh kognisi tertentu tidak mesti diatur oleh pengaturan struktur formal. Begitu juga, keanggotaan dalam asosiasi masyarakat tertentu tidak mesti tidak memiliki ikatan pribadi, disebabkan bisa saja partisipasi dalam kelompok tersebut tidak bersifat sukarela. Interaksi sosial memiliki dampak modal melalui kehadiran efeknya yang bisa dicapai melalui tingkat kognisi maupun struktural, seperti sebuah perkumpulan olahraga memiliki nilai dan tujuan jangka panjang dalam interaksi sosialnya, tetapi bentuk kognisi modal sosialnya terbentuk melalui interaksi sosial berulang yang terjadi pada akhir pertandingan serta memiliki efek jangka panjang bahkan lebih luas dari anggota organisasi tersebut.

Tidak hanya itu, saluran manfaat modal sosial yang mempengaruhi pembangunan diantaranya terdiri dari beberapa unsur yang saling berhubungan, seperti saling tukar menukar informasi serta tindakan dan pengambilan keputusan kolektif yang saling menguntungkan. Paul Collier mempelajari konsep modal sosial dari perspektif ekonomi, dia menjelaskan modal sosial secara ekonomi bermanfaat disebabkan oleh interaksi sosial setidaknya menghasilkan 3 bentuk eksternalitas. Pertama, dia menyediakan transmisi pengetahuan tentang prilaku orang lain serta hal ini mengurangi masalah opportunitas. Kedua, dia menyediakan transmisi pengetahuan tentang teknologi dan pasar, serta hal ini mengurangi masalah kegagalan informasi pasar. Ketiga, dia bisa mengurangi persoalan free riding serta dia membantu tindakan kolektif. Selanjutnya, Coliier membedakan antara interaksi sosial yang bersifat resiprosikal atau unidirectional; serta bentuk terorganisisr atau informal. Contohnya, transmi pengetahuan adakalanya tergantung pada penyatuan (pooling) informasi yang terjadi pada interaksi resiprosikal seperti melalui jaringan (networks) dan perkumpulan (terorganisir), atau tergantung pada copy yang hanya membutuhkan interaksi yang tidak langsung (uninderectional).

Implikasi modal sosial terhadap orang miskin dapat dilihat dari tipologi ini. Contohnya, proses copy bisa jadi secara intrinsik mempersamakan, dimana jaringan yang ada (networks) menyingkirkan orang miskin disebabkan mereka kurang pengetahuan terhadap penyatuan tersebut. Beberapa kasus menunjukkan pedagang yang memiliki jaringan baik punya informasi harga dan kredibilitas pelanggan yang bisa meningkatkan marjin keuntungan mereka (Grootaert and Bastelaer; 2001; 6). Disamping berfungsi sebagai sharing informasi, modal sosial dalam 
bentuk jaringan hubungan (networks) dan asosiasi juga berfungsi untuk membantu aksi kolektif dan pengambilan keputusan dengan cara meningkatkan manfaat pelaksanaannya melalui prilaku yang diharapkan atau meningkatkan biaya yang harus dikeluarkan dari prilaku yang tidak diharapkan.

Modal sosial juga harus dilihat pada ujungnya bisa dilihat kontribusinya dalam konteks pembangunan berkelanjutan. Pembangunan berkelanjutan didefinisikan sebagai sebuah proses dimana generasi masa depan memperoleh sejumlah atau lebih pendapatan perorangan sejumlah yang tersedia saat ini (Scrageldin, 1986). Pada umumnya hal ini mencakup modal sumberdaya alam, modal fisik atau modal yang dihasilkan, serta sumberdaya manusia sebagai bentuk kemakmuran bangsa dimana pembangunan ekonomi tumbuh diatasnya. Tiga tipe modal ini dikenali menentukan secara parsial proses pertumbuhan ekonomi disebabkan oleh pandangan bahwa iunteraksi aktor ekonomi dan pengorganisasian mereka menghasilkan pertumbuhan dan pembangunan Missing linknya adalah pada modal sosial (Grootaert, 1997). Dalam konseptualisasi yang lebih luas terdapat sedikit perbedaan pendapat tentang relevansi modal sosial. Tidak terdapat konsensus pada bagian mana interaksi sosial serta keuntungan organisasi mana yang menguntungkan label modal sosial, maupun validitas penggunaan istilah "modal" untuk menggambarkannya.

Sebagian akademisi mempertanyakan penggunaan istilah "modal" dalam memahami interaksi dan sikap. Namun, modal sosial memperlihatkan beberapa sejumlah kharakteristik yang membedakannya dari bentuk modal lainnya. Pertama, berbeda dari modal fisik maka modal sosial seperti halnya dengan modal manusia bisa diperoleh sebagai hasil dari penggunaanya Dengan kata lain, modal sosial merupakan input kearah dan output aksi kolektif. Dalam pengertian luas, interaksi sosial diperoleh dari tujuan untuk menghasilkan output keuntungan timbal balik, kuantitas dan kualitas interaksi inisejatinya akan meningkat. Kedua, meskipun bentuk modal lain memberikan dampak produktif potensial dalam tipe ekonomi primitif (Robinson Crusoe), tetapi modal sosial tidak; Upaya untuk menciptakan dan mendayagunakan modal sosial setidaknya membutuhkan sedikitnya 2 orang. Dengan kata lain, modal sosial memiliki ciri khas barang publik yang memiliki implikasi langsung untuk mengoptimalkan tingkat produksinya. Seperti halnya dengan, modal sosial memiliki kecenderungan untuk berkurang hasilnya disebabkan oleh tidak komplit, terjadinya internalisasi kolektif dari eksternalitas positif yang melekat dalam produksinya.

Modal sosial memiliki atribut lainnya yang membedakannya dari modal lainnya, diantaranya. Pertama, untuk menghasilkannya lebih hemat dibandingkan degan investasi, setidaknya pada waktu dan upaya, dia tidak selalu berwujud uang yang lebih signifikan. Hubungan saling percaya diantara anggota kelompok olahraga atau organisasi professional seringkali membutuhkan pertemuan dan hubungan bertahun untuk berkembang, seperti studi Putnam tentang kelompok masyarakat sipil di Itali diperlukan beberapa generasi untuk mmbentuk modal sosial agar sepenuhnya efektif, seperti halnya dengan konflik diberbagai tempat lain di dunia kepercayaan (trust) lebih mudah dirusak daripada dibangun. Karenanya, terdapat pengeluaran tertentu yang harus dikeluarkan memelihara modal sosial, biasanya dalam bentuk waktu.

Modal sosial merupakan aset asli yang tidak hanya sekedar bentuk organisasi sosial atau nilai-nilai sosial. Pada sisi input, dimensi ini berada dalam bentuk investasi yang dibutuhkan untuk menciptakan asset jangka panjang; pada sisi output berada dalam kemampuan untuk menghasilkan sejumlah manfaat. Hasil studi SCI memperlihatkan modal bisa memperkuat output secara langsung serta mendorong produktifitas lebih tinggi, seperti modal dan modal fisik (kasus penggunaan ADD dalam sektor pengembangan masyarakat, pembangunan dan pemerintahan). Tantangan peneliti adalah memberikan isi yang bermakna dan pragmatis 
kandungan yang banyak dari modal sosial dalam setiap konteks, serta mendefinisikannya dan mengukurnya sesuai dengan indikator yang tepat.

\section{METODE}

Metode penelitian adalah sesuatu yang perlu mendapatkan perhatian serius dalam pelaksanaan penelitian. Metode penelitian pada dasarnya adalah suatu teknik atau cara yang dilakukan dalam pelaksanaan penelitian terhadap sesuatu objek kajian. Metode yang digunakan akan berdampak terhadap jawaban-jawaban permasalahan yang muncul dalam rumusan masalah. Pendekatan yang digunakan dalam pelaksanaan program pengabdian kepada masyarakat adalah pendekatan partisipatif atau Participatory Rural Appraisal (PRA) yaitu melibatkan semua elemen masyarakat mulai dari ibu-ibu rumah tangga (PKK) dan pemuda. Kegiatan pengabdian ini dilakukan oleh tim pengabdian Jurusan Ilmu Politik Unand, yang terdiri dari dosen-dosen PNS dan dosen kontrak yang ada di Jurusan Ilmu Politik. Pengabdian ini dilakukan di Aula Kelurahan Limau Manis Selatan tanggal 24 Oktober 2019. Kegiatan pengabdian ini diawali dengan kata sambutan dari Lurah Limau Manis Selatan, Miftahur Rahmha, SSTP.,MM, dilanjutkan dengan kata sambutan dan sekaligus pembukaan kegiatan pengabdian oleh Ketua Jurusan Ilmu Politik, Dr. Indah Adi Putri,M.IP. Kegiatan pengabdian ini diikuti oleh 25 (dua puluh lima) orang peserta dari masyarakat Kelurahan Limau Manis yang telah ditunjuk oleh pihak kelurahan untuk mewakili mengikuti kegiatan ini.

Pengabdian ini dibagi ke dalam 3 (tiga) sesi. Sesi pertama, penyampaian materi tentang konsep modal sosial. Pada sesi ini, kegiatan pengabdian difasilitatori oleh Dr. Bakaruddin Rasyidi, MS. Pada kesempatan ini dijelaskan bahwa modal sosial merupakan ikatan-ikatan sosial yang berguna dalam berbagai aspek, dimana modal sosial dapat berbentuk kerjasama. Adapun kerjasama yang dimaksud adalah sebuah upaya penyesuaian serta koordinasi tingkah laku yang dibutuhkan untuk memenangkan sebuah kompetesi termasuk dalam konteks politik. Di samping itu, modal sosial juga dapat mengatasi konflik prilaku dari seseorang atau kelompok yang menghambat seseorang/kelompok lain sehingga tingkah laku itu dapat seirama dengan yang lain. Putnam juga menjelaskan bahwa modal sosial dapat juga diartikan sebagai suatu ciri-ciri kehidupan sosial jaringan, norma, serta kepercayaan (trust) atau rasa percaya yang bisa membuat semua warga masyarakat tersebut bertindak efektif dalam rangka mencapai tujuan tertentu.

\section{PEMBAHASAN}

Modal sosial pada tingkatan mikro adalah pada jaringan hubungan individu, konsep modal sosial ini diantaranya dikemukakan oleh Robert Putnam (1993) yang mengartikannya sebagai bentuk organisasi sosial, seperti jaringan hubungan individu atau rumah tangga, serta kumpulan nilai-nilai dan norma yang menciptakan eksternalitas yang berbentuk positif. Tetapi, perkembangan lebih lanjut mendorong Putnam untuk mengartikan eksternalitas ini tidak hanya berbentuk positif, tetapi juga negatif. Eksternalitas negatif ini dihasilkan oleh interaksi antara inividu Eksternalitas negatif ini dihasilkan oleh interaksi antara inividu, eksternalitas negatif hanya menguntungkan warga kelompok, tetapi tidak warga diluar kelompok tersebut. Selanjutnya, pengertian modal sosial secara mikro ini dikembangkan oleh James Colemen (1998) pada tingakan messo. Pengertian modal sosial menurut Coleman adalah adalah variasi berbagai masyarakat (entities) yang terdiri dari dari beberapa aspek struktur sosial, serta memfasilitasi tindakan dan aktor tertentu baik aktor pribadi atau kelompok dalam struktur tersebut (p. 558) 
yang secara implisit hanya menilai pada hubungan antar kelompok daripada individu. Pengertian ini memperluas konsep ini tidak hanya pada sisi hubungan kelompok vertikal dan horizontal, tetapi prilaku pada masyarakat lain seperti perusahaan. Pengertian hubungan vertikal mengandung hubungan hierarkhi, serta distribusi tidak merata kekuasaan dikalangan anggotanya.

Konsep ketiga modal sosial mengandung lingkungan sosial dan politik, serta membentuk struktur sosial yang memungkinkan norma berkembang. Pandangan ini disamping mengandung hubungan informal, serta seringkali bersifat lokal dan hierarkhis seperti yang terdapat pada konsep mikro dan messo modal sosial, tetapi juga mengandung hubungan pada tingkatan makro yang lebih bersifat resmi dan terlembaga, seperti rejim politik, aturan hukum, sistem peradilan, serta kebebasan sipil dan politik. Pandangan ini diantaranya dihasilkan melalui karya Mancur Olson (1982) dan Douglas North (1990), mereka menjelaskan institusi ini memiliki efek mendasar terhadap tingkat dan pola pembangunan ekonomi.

Terdapat hubungan komplementer yang sangat tinggi antara perkumpulan herarkhis maupun vertikal dengan institusi tingkat makro ini, serta hubungan (coexistence) tersebut memaksimumkan dampak modal sosial dan outcome social dan egonomi yang dihasilkannya. Contohnya, intitusi makro bisa menyediakan lingkungan yang memungkinkan perkumpulan lokal bisa berkembang dan tumbuh; perkumpulan lokal ini bisa menunjang institusi regional dan nasional serta menambah tingkat stabilitas keduanya.

Pengaruh modal sosial terhadap pembangunan dihasilkan dari interaksi antara dua tipe khas modal sosial baik pada tingkat mikro, messo atau makro, diantaranya pada struktur dan kognitif. Struktur modal sosial menyediakan saling tukar menukar informasi, serta tindakan kolektif dan pengambilan keputusan melalui peranan tersedia, jaringan sosial, struktur sosial lainnya yang disediakan oleh aturan, prosedur dan preseden. Sepertinya, hal ini bersifat objektif serta dapat diamati susunannya dari luar. Sedangkan modal sosial kognitif menunjuk kepada norma yang disepakati, nilai-nilai, kepercayaan, sikap serta keyakinan. Karenanya, ini bersifat lebih subyektif dan konsep yang tidak bisa diraba (Uphoff, 2000).

Aspek kognitif dan struktural tidak mesti berhubungan sama lain, seperti kerjasama diantara tetangga yang diikat oleh kognisi tertentu tidak mesti diatur oleh pengaturan struktur formal. Begitu juga, keanggotaan dalam asosiasi masyarakat tertentu tidak mesti tidak memiliki ikatan pribadi, disebabkan bisa saja partisipasi dalam kelompok tersebut tidak bersifat sukarela. Interaksi sosial memiliki dampak modal melalui kehadiran efeknya yang bisa dicapai melalui tingkat kognisi maupun struktural, seperti sebuah perkumpulan olahraga memiliki nilai dan tujuan jangka panjang dalam interaksi sosialnya, tetapi bentuk kognisi modal sosialnya terbentuk melalui interaksi sosial berulang yang terjadi pada akhir pertandingan serta memiliki efek jangka panjang bahkan lebih luas dari anggota organisasi tersebut.

Sementara itu, saluran manfaat modal sosial yang mempengaruhi pembangunan diantaranya terdiri dari beberapa unsur yang saling berhubungan, sepeti saling tukar menukar informasi serta tindakan dan pengambilan keputusan kolektif yang saling menguntungkan. Paul Collier mempelajari konsep modal sosial dari perspektif ekonomi, dia menjelaskan modal sosial secara ekonomi bermanfaat disebabkan oleh interaksi sosial setidaknya menghasilkan 3 bentuk eksternalitas. Pertama, dia menyediakan transmisi pengetahuan tentang prilaku orang lain serta hal ini mengurangi masalah opportunitas. Kedua, dia menyediakan transmisi pengetahuan tentang teknologi dan pasar, serta hal ini mengurangi masalah kegagalan informasi pasar. Ketiga, dia bisa mengurangi persoalan free riding serta dia membantu tindakan kolektif. Selanjutnya, Collier membedakan antara interaksi sosial yang bersifat resiprosikal atau unidirectional; serta bentuk terorganisisr atau informal. Contohnya, transmisi pengetahuan adakalanya tergantung pada penyatuan (pooling) informasi yang terjadi pada interaksi resiprosikal seperti melalui 
jaringan (networks) dan perkumpulan (terorganisir), atau tergantung pada copy yang hanya membutuhkan interaksi yang tidak langsung (indirectional).

Implikasi modal sosial terhadap orang miskin dapat dilihat dari tipologi ini. Contohnya, proses copy bisa jadi secara intrinsik mempersamakan, dimana jaringan yang ada (networks) menyingkirkan orang miskin disebabkan mereka kurang pengetahuan terhadap penyatuan (pooling) tersebut. Beberapa kasus menunjukkan pedagang yang memiliki jaringan baik punya informasi harga dan kredibilitas pelanggan yang bisa meningkatkan marjin keuntungan mereka (Grootaert and Bastelaer; 2001; 6). Disamping berfungsi sebagai sharing informasi, modal sosial dalam bentuk jaringan hubungan (networks) dan asosiasi juga berfungsi untuk membantu aksi kolektif dan pengambilan keputusan dengan cara meningkatkan manfaat pelaksanaannya melalui prilaku yang diharapkan atau meningkatkan biaya yang harus dikeluarkan dari prilaku yang tidak diharapkan.

Modal sosial harus dilihat pada ujungnya bisa dilihat kontribusinya dalam konteks pembangunan berkelanjutan. Pembangunan berkelanjutan didefinisikan sebagai sebuah proses dimana generasi masa depan memperoleh sejumlah atau lebih pendapatan perorangan sejumlah yang tersedia saat ini (Scrageldin, 1986). Pada umumnya hal ini mencakup modal sumberdaya alam, modal fisik atau modl yang dihasilkan, serta sumberdaya manusia sebagai bentuk kemakmuran bangsa dimana pembangunan ekonomi tumbuh diatasnya. Tiga tipe modal ini dikenali menentukan secara parsial proses pertumbuhan ekonomi disebabkan oleh pandangan bahwa interaksi aktor ekonomi dan pengorganisasian mereka menghasilkan pertumbuhan dan pembangunan missing linknya adalah pada modal sosial (Grootaert, 1997). Dalam konseptualisasi yang lebih luas terdapat sedikit perbedaan pendapat tentang relevansi modal sosial. Tidak terdapat konsensus pada bagian mana interaksi sosial serta keuntungan organisasi mana yang menguntungkan label modal sosial, maupun validitas penggunaan istilah "modal" untuk menggambarkannya.

Modal sosial memiliki atribut lainnya yang membedakannya dari modal lainnya, diantaranya. Pertama, untuk menghasilkannya lebih hemat dibandingkan degan investasi, setidaknya pada waktu dan upaya, dia tidak selalu berwujud uang yang lebih signifikan. Hubungan saling percaya diantara anggota kelompok olahraga atau organisasi professional seringkali membutuhkan pertemuan dan hubungan bertahun untuk berkembang, seperti studi Putnam tentang kelompok masyarakat sipil di Itali diperlukan beberapa generasi untuk mmbentuk modal sosial agar sepenuhnya efektif, seperti halnya dengan konflik diberbagai tempat lain di dunia kepercayaan (trust) lebih mudah dirusak daripada dibangun. Karenanya, terdapat pengeluaran tertentu yang harus dikeluarkan memelihara modal sosial, biasanya dalam bentuk waktu.

Modal sosial merupakan aset asli yang tidak hanya sekedar bentuk organisasi sosial atau nilai-nilai sosial. Pada sisi input, dimensi ini berada dalam bentuk investasi yang dibutuhkan untuk menciptakan assets jangka panjang; pada sisi output berada dalam kemampuan untuk menghasilkan sejumlah manfaat. Hasil studi SCI memperlihatkan modal sosial bisa memperkuat output secara langsung serta mendorong produktifitas lebih tinggi, seperti modal ekonomi dan modal fisik. Pada sesi ini, selain dilakukan penyampaian materi secara ceramah, juga dilakukan brainstorming pengetahuan peserta mengenai modal sosial yang mereka miliki di lingkungan mereka sendiri. Sehingga didapatkan kesepakatan bersama bahwa di Kelurahan Limau Manis terdapat kelompok-kelompok yang memiliki modal sosial, di antaranya kelompok ada dalam kelompok PKK, majlis taklim, kelompok yasinan, Kelompok Karang Taruna, Kelompok Pemuda, dll. Ada beberapa modal sosial yang terdapat dalam kelompok-kelompok sosial di masyarakat Kelurahan Limau Manis yaitu masih adanya hubungan kekerabatan yang kental antarmasyarakat. Masyarakat masih menggunakan media konvensional dalam melakukan aktivitas sosialnya dengan cara mempererat jalinan silaturrahmi, masih mempertahankan nilai- 
nilai kejujuran dan kepercayaan di tengah-tengah masyarakat dan juga masih terjaganya masjid/mushalla sebagai sarana dalam menyampaikan informasi suka maupun duka di masyarakat, misal ketika ada masyarakat yang meninggal maka pertama sekali akan dilakukan pengumuman di masjid/mushalla dan penyelenggaraan jenazah dilakukan secara gotong royong dengan adanya pembagian tugas di antara masyarakat, ada yang membawa kain kapan, ada yang membawa makanan untuk keluarga yang kemalangan. Di sesi ini juga tereksplorasi masih kentalnya hubungan kekeluargaan di tengah-tengah masyarakat.

Selanjutnya dilakukan curah pendapat dari peserta mengenai kesulitan dalam menjalankan program pemerintah yang terdapat di kelurahan karena masyarakat belum bisa memanfaatkan modal sosial yang sudah ada di lingkungan mereka sendiri. Masyarakat juga mengemukakan kurangnya partisipasi mereka dalam mendukung program-program kelurahan karena masyarakat merasa tidak dilibatkan secara 'serius' oleh pemerintah kelurahan.

Setelah dilakukannya penggalian masalah-masalah mengenai kurangnya keterlibatan masyarakat dalam mendukung kegiatan-kegiatan pemerintah kelurahan terutama dalam mendukung tersalurkannya dana-dana kelurahan yang dianggarkan oleh pemerintah kota Padang, masyarakat bertekad untuk peduli ketika adanya program yang diberikan kepada kelurahan dengan cara memanfaatkan modal-modal sosial yang terdapat di lingkungan mereka sendiri, seperti gotong royong, meningkatkan silaturahmi antarsesama warga dan antar warga dengan pemerintah kelurahan serta musyawarah mufakat dalam mencari solusi atas kendala yang dihadapi dalam menjalankan program tersebut.

Disamping itu juga dilakukan role play pemanfaatan modal sosial masyarakat dengan kemungkinan banyaknya hambatan dan tantangan yang akan ditemui di lapangan ketika sebuah kesepakatan telah dilakukan antarkelompok-kelompok masyarakat. Berdasarkan, dari 5 (lima) kelompok yang dibentuk dari peserta pengabdian, hanya 1 kelompok yang konsisten dengan kesepakatan diawal untuk menjaga kekompakan dan konsistensi dengan kesepakatan tersebut, sementara itu 4 (empat) kelompk cenderung untuk mengikari kesepakatan dan lebih cenderung mengutamakan kepentingan kelompok mereka sendiri.

\section{KESIMPULAN}

Kekuatan modal sosial di masyarakat Limau Manis Selatan adalah pada ikatan kekeluargaan dan silaturahmi yang kuat. Ini mampu menjadi penopang segala kebijakan yang akan dirumuskan dalam pembangunan. Ikatan yang menjadi modal sosial ini harus terus dipelihara, dengan sejumlah persyaratan yang berkaitan dengan karakter masyarakat Minang. Beberapa karakter tersebut antara lain; patuh dan amanah terhadap aturan bersama yang sudah disepakati. Aturan yang ada tidak boleh dilanggar, jika dilanggar ada sanksi. Kesepakatan sulit dicapai jika lemah terhadap orang-orang yang mengacaukan kesepakatan, tidak memikirkan kepentingan sendiri, jujur dan ikhlas, memiliki ikatan yang kuat serta berpikiran positif. Di samping itu, ada beberapa hal yang akan membuat syarat-syarat tersebut diingkari dan dikhianati, yaitu lebih mementingkan ego sektoral maupun ego pribadi, adanya kepentingan luar yang ingin memecah kelompok yang sudah kuat, ada anggota kelompok yang berada pada posisi lemah dalam bernegosiasi, sulitnya untuk bersikap ikhlas dan jujur dalam menjalankan program yang ada, dan masih ada kesenjangan sosial yang berpengaruh terhadap pola pikir dalam kelompok masyarakat serta kurang bijaksananya pimpinan maupun anggota kelompok dalam menyikapi perkembangan yang ada.

Didapat kesimpulan yang disepakati oleh semua perserta, yaitu: pertama, Modal sosial akan hancur jika tidak ada tabayun/cek dan ricek terhadap setiap perkembangan atau informasi baru. Kedua, modal sosial akan kuat jika tujuan bersama diketahui dan disepakati semua elemen 
masyarakat. Ketiga, semua pihak harus memiliki niat dan motivasi yang sama. Keempat, dalam masyarakat akan ada kelompok-kelompok yang memiliki masalah-masalah, setiap kelompok memiliki aturan yang harus dipatuhi, sepanjang aturan diikuti, maka organisasi atau kelompok akan terus berjalan. Kelima, untuk kekompakan masyarakat, harus mengikuti keputusan bersama. Keenam, hilangkan rasa curiga dan kesombongan pribadi.

\section{DAFTAR PUSTAKA}

BPS Kota Padang, 2018, Kecamatan Pauh dalam Angka 2018, Padang: Sarana Multi Abadi.

Creswell, John W, 2009, Research Design, Pendekatan Kualitatif, Kuantitatif dan Mixed, Yogyakarta : Pustaka Pelajar.

Danim, Sudarwan, 2002, Menjadi Peneliti Kualitatif, Bandung: Pustaka Setia.

Field, John. 2018. Modal Sosial. Bantul: Kreasi Wacana.

Grootaertm Christiaan \& Thierry van Bastelaer. 2001. Understanding and Measuring Social Capital; Social Capital Initiative Working Paper No 24.

Janesick, Valerie J., Tarian Desain Penelitian Kualitatif, dalam Denzin,Norman K dan Yvonna S.Lincoln (eds),2009, Handbook of Qualitatif Research (Terj), Jakarta: Pustaka Pelajar.

Kato, Tsuyoshi. 2005. Adat Minangkabau dan Merantau dalam Perspektif Sejarah. Terjemahan. Jakarta: Balai Pustaka.

Moleong, Lexy J. .1999, Metodologi Penelitian Kualitatif, Bandung : Remaja Rosdakarya.

Nurmalasari, Dewi, 2011, Modal Sosial Calon Legislatif Perempuan dalam Pemilu 2009 di Kabupaten Indramayu, Jurnal Aspirasi Vol.1 No 2 Februari 2011.

Newman, Lawrence, 1997. Social Research Methods: Qualitatif and Quantitative Approaches, 3 ${ }^{\text {rd }}$, Boston: Allyn and Bacon.

Tamrin, Asrinaldi dan Indah Adi Putri. 2013. Model Transfer Dana Perimbangan Dan Pemerataan Kemampuan Fiskal Dalam Pelaksanaan Otonomi Daerah. Laporan Penelitian Hibah Bersaing. Padang: LPPM Universitas Andalas.

Tamrin, Yanita, Yoserizal, 2016, Pengembangan Model Nagari Adat di Bawah Rezim UU Desa dan Implikasinya dalam Penyelenggaraan Pemerintahan Terendah Di Sumatera Barat, laporan penelitian Penelitian Unggulan Perguruan Tinggi (PUPT), Universitas Andalas, Padang.

Yoserizal \& Asrinaldi. 2013. Quasi Otonomi Pada Pemerintahan Terendah Nagari Simarasok Di Sumatera Barat Dan Desa ponjong di Daerah Istimewa Yogyakarta. Sosiohumaniora, 15(2): 178-193.

Yoserizal \& Asrinaldi. 2011. Praktik Pemerintahan Terendah dalam Pembangunan dan Implikasinya Terhadap Demokrasi Lokal Di Sumatera Barat. Jurnal Transformasi Pemerintahan, 3(2):85-103. 